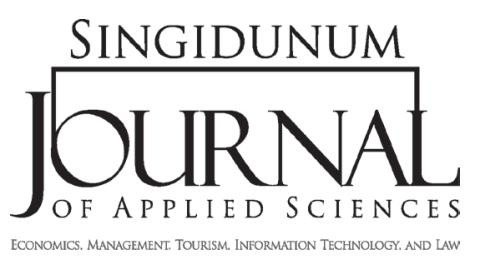

\section{THE EFFECTS OF CROSS-BORDER TOURIST PURCHASES ON RETAIL PERFORMANCE}

\author{
Radojko Lukić \\ University of Belgrade, Faculty of Economics \\ 6 Kamenicka Street, Belgrade, Serbia
}

\begin{abstract}
:
One of the major novelties in modern retail that is gaining more and more prominence is the concept of cross-border shopping. Factors affecting the rapid development of cross-border shopping are numerous, such as price differentiation, quality, convenience, demographic and social characteristics, good organizational structure developed in modern retail and many others. Among the influencing factors, the role of price differentiation of goods and services is very important and it is also affected by numerous factors. Those are: value added tax, profit margins, operating costs, exchange rates, inflation, differentiation of organizational structure in retail, the application of advanced information and communication technology and others. Cross-border shopping is, in itself, very important influential factor for the development of tourism, target retail market, performance of retail companies and living standard. Altogether, this has a positive effect on the overall performance of the national economy.
\end{abstract}

SINGIDUNUM JOURNAL 2012, 9 (2): 21-26

ISSN 2217-8090

UDK 338.488.3:339.378.2

Review paper/Pregleni naučni rad

\section{Key words:}

price differentiation,

factors,

travel buyers,

performance.

\section{INTRODUCTION}

With all the foregoing in mind, the primary objective of this study is to survey the literature on the given subject and analyze all aspects of the empirical data relevant for understanding the impact of cross-border shopping on retail performance. This should provide the basis for global improvement of the overall performance of retail companies that also render a service to cross-border shoppers.

Cross-border shopping has recently become increasingly important as an economic category, which is quite understandable when one takes into account the fact that it affects the development of tourism, the conquest of new retail markets, tax revenues, the performance of retail companies and other economic sizes. For such reasons, the concept of crossborder purchases has been intensively researched in both theory and practice (Leal et al. 2009; Leal et al. 2010; Gopinath et al. 2011; Hsu, 2011; Patrick, 2011; Singh, 2011; Lukić, 2011).
Relying on the analysis of the relevant literature and empirical data, this paper seeks to envisage the complex problems of cross-border shopping; primarily, by observing the impact it has on the performance of retail companies that render a service to cross-border shoppers. This should represent a basis for more efficient performance management of cross-border purchases of goods and services, which is seen as a particular target segment of the retail market.

An abundant amount of literature is dedicated to studying the problems of efficiency of cross-border purchases. Namely, this issue can be examined by relying on different perspectives, such as cross-border shopping trend, factors that influence the development of cross-border shopping, cross-border shopping motives, marketing channels of cross-border shopping, the structure of cross-border purchases by countries, regions and product categories, the effects of cross-border purchases on tax revenue, cross-border trade as a factor of tourism development, etc. 
This paper examines all these aspects of the subject matter in the context of the impact cross-border shopping on retail performance.

The issue of cross-border purchases, considering the complexity, can be explored through a variety of hypotheses. Relying on the clearly defined objective, the hypothesis (H1) - that the cross-border shopping represents an increasingly important factor for the performance of retail companies, mostly due to the price differentiation and rising poverty of customers in many countries - is particularly tested in this paper. Related to this, the hypothesis $(\mathrm{H} 2)$ is examined - the impact of the effective cross-border purchase management (general and online) on the performance of retail companies (Suchánek, 2010; The European Consumer Centers' Network, 2011).

Method that is primarily used to prove these hypotheses is review of relevant literature.
In order to verify them, original empirical data collected from various sources (articles, statistics, publications) are analyzed as well.

\section{CROSS-BORDER SHOPPING: AN ANALYTICAL MODEL}

Purchasing has recently become one of the major "enjoying" activities for many tourists. Moreover, we could say it represents the primary motive that triggers many tourists to visit some destinations.

There are various macro- and micro-analytical factors influencing the behavior of tourists. Market (macro-factors) and socio-economic, motivational, customer characteristics (micro factors) affect cross-border shopping. Figure 1 presents the analytical model of cross-border purchases.

The economic and cultural significance of crossborder shopping in tourism is immense. There are

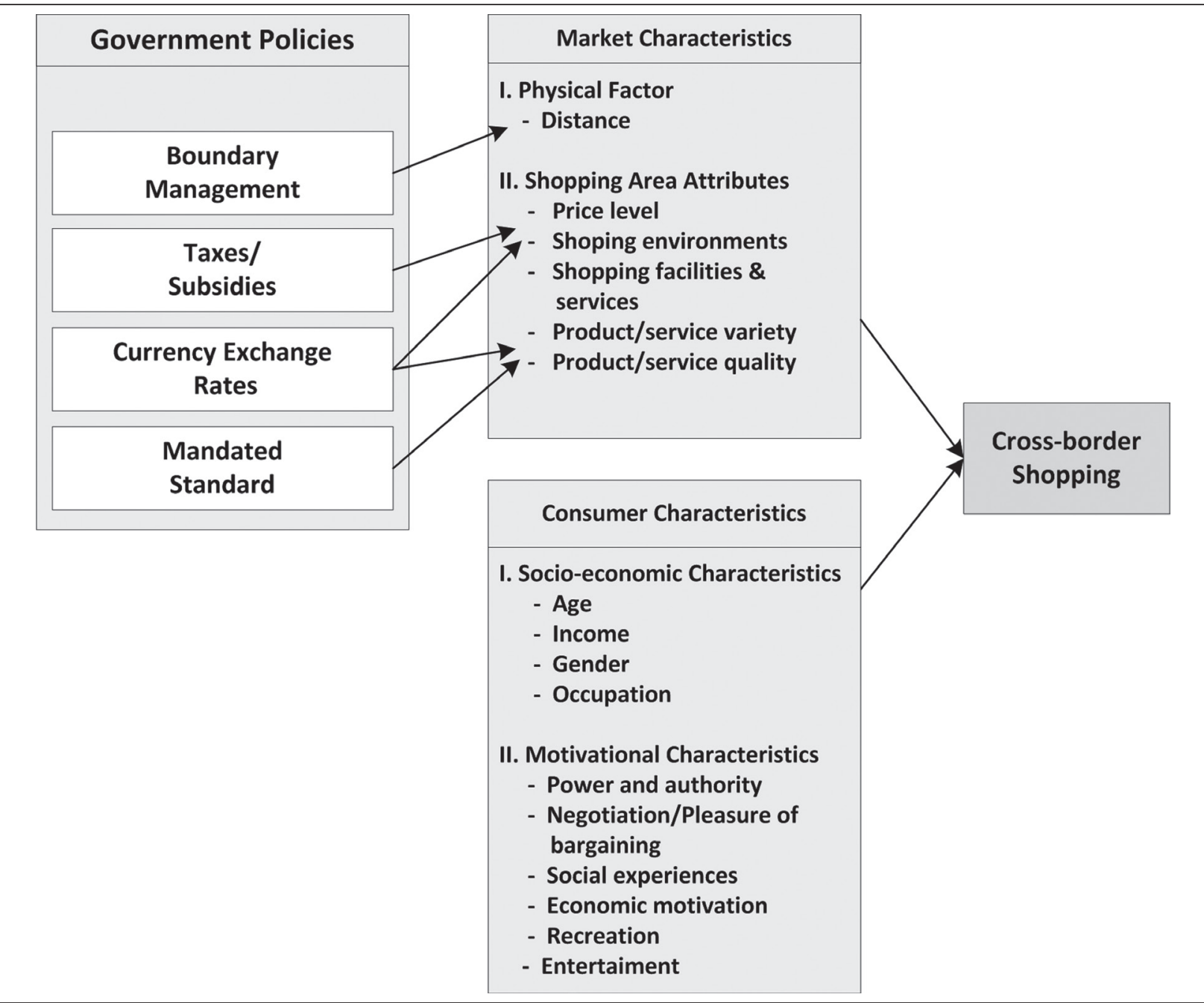

Figure 1 - Cross-Border Shopping: An Analytical Model

Source: Lau et al. (2005) 


\begin{tabular}{lcccc}
\hline \multicolumn{1}{c}{ Trip Duration: } & \multicolumn{2}{c}{ Same day } & \multicolumn{2}{c}{ Overnight } \\
\hline Residence of Travellers: & U.S. & Canada & U.S. & Canada \\
\hline Business Affairs & 7.5 & 7.4 & 7.6 & 7.5 \\
\hline Visit friends / relatives & 15.2 & 8.8 & 22.8 & 22.2 \\
\hline Pleasure or personal trip & 43.1 & 53.2 & 62.3 & 64.6 \\
\hline Commuting to work & 2.3 & 6.0 & - & - \\
\hline Other & 21.1 & 15.4 & 7.2 & 5.5 \\
\hline Not stated & 10.8 & 9.2 & 0.1 & 0.2 \\
\hline Total Respondents ('000s) & 304 & 445 & 226 & 264 \\
\hline
\end{tabular}

Table 1 - Reasons for Crossing the Border, 1990-2010 (percent)

Source: Chandra, A. (2011)

numerous reasons for cross-border shopping of tourists. They are illustrated in Table 1.

The study, relying on the example of cross-border purchases of US-Canada, found that the key motive for tourists was price differentiation; $10 \%$ exchange rate appreciation raises the average crossborder welfare by $2.1 \%$. Distance greatly restricts cross-border shopping, with the assumed cost of $\$ 0.9$ per mile. If these costs are considerable they can deter tourists - customers from using the differentiated favorable prices, directing them towards other more favorable cross-border retail segments (Chandra, 2011).

\section{FACTORS AFFECTING THE PURCHASE AS A MOTIVE FOR THE JOURNEY}

Mass consumption and tourism are very essential factors of economic growth in many countries. This is demonstrated by a number of empirical studies conducted (Tömöri, 2010). Numerous factors - such as the motive for the journey - influence buying, as it can be seen from Figure 2.

Cross-border shopping represents one of the most significant factors for the development of tourism in certain foreign countries (Timothy and Butler, 1995). It is also the determinant of the in-
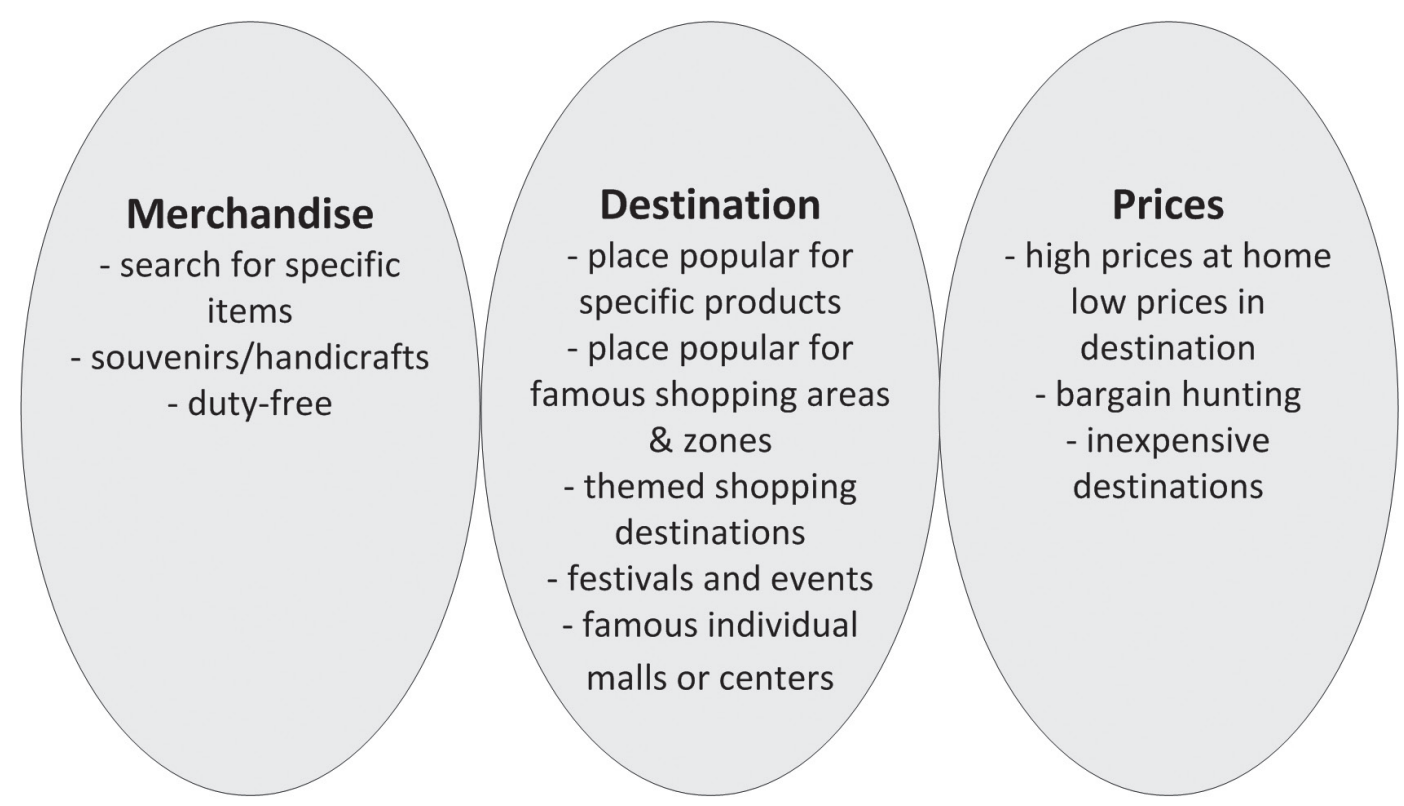

Figure 2 - Factors affecting the purchase as a motive for the journey

Source: Tömöri, M. (2010) 


\begin{tabular}{lcc}
\hline \multicolumn{1}{c}{ Segment } & $\begin{array}{c}\text { Turnover segment in retail } \\
\text { commerce generated by } \\
\text { tourists 2004 (Bill. } € \text { ) }\end{array}$ & $\begin{array}{c}\text { Touristic turnover in retail } \\
\text { commerce 2010 (Bill. } € \text { ) }\end{array}$ \\
\hline One-day tourists in total (Customers coming from very far) & 9.2 & $10.3-11.0$ \\
\hline$\ldots$ among which: German one-day-tourists & 7.5 & $8.1-8.6$ \\
\hline$\ldots$ among which: one-day foreign tourists & 1.7 & $2.2-2.4$ \\
\hline Visitors requesting accommodation total & 3.3 & $4.1-4.6$ \\
\hline$\ldots$ among which: Germans & 2.5 & $3.0-3.4$ \\
\hline$\ldots$ among which: Foreign tourists & 0.8 & $1.1-1.2$ \\
\hline Sum & 12.5 & $14.4-15.6$
\end{tabular}

Table 2 - Estimated retail sales potential of Germany on the basis of cross-border shopping, 2010.

Source: Friedrich and Sattler (2005)

creased retail sales. Data in Table 2 clearly point that, in the reporting period, sales generated by tourists increased in German retailing.
In principle, cross-border shopping can be seen as an economic or tourist activity, as described in Figure 3.

\begin{tabular}{|c|c|c|c|}
\hline & & \multicolumn{2}{|c|}{ Length of stay } \\
\hline & & one or more nights & same day returns \\
\hline \multirow{3}{*}{$\begin{array}{c}\text { Reason / motivation for cross-border } \\
\text { shopping }\end{array}$} & pleasure & 1 & 3 \\
\hline & pleasure and economic & 2 & 4 \\
\hline & economic & 5 & 6 \\
\hline
\end{tabular}

Figure 3 - A hypothetical model of cross-border customer

Source: Tömöri, M. (2010)

The meaning of certain fields on a given image is clear in itself. For instance, the field 1 represents cross-border customers who stay in a foreign country for at least one night and who are motivated by pleasure. The field 6 includes economic motives of cross-border buyers who return home the same day, which is why they cannot be treated as tourists belonging to this category. Analysis of the meaning of other fields in the table is similar.

During a visit to the United States, Chinese tourists are very interested in purchasing different products, from watches and jewellery to the footwear and healthy food. They believe that the American products have the same quality but lower prices compared to the similar products at home. Purchases done by the respective tourists are certainly facilitated by the acceptance of Chinese credit cards in American stores (Xu and McGehee, 2012).

In any case, the local buyers and foreign tourists as customers have different perceptions of values in the same country. It is confirmed by the results of the two customer groups - local and tourist shoppers in Hong Kong. It certainly has some implica- tions on strategic operations of global retailers (LIoyd et al. 2011).

\section{DUTY-FREE SHOPS}

Foreign tourists make considerable purchases in duty-free shops located on the borders. Prices in those shops are much lower than in other shops. They, therefore record a significant increase in sales and financial performance. Thus, for example, the airport retailer Dubai Duty Free (one of the largest in the world) had an increase of $16.4 \%$ in sales in late September 2011 compared to the same period in 2010 (Peter and Anandkumar, 2011). Especially perfumes, jewellery and alcohol are sold in these stores (Table 3).

\section{GROSS MARGIN}

High gross margin is typical for duty-free shops as an indicator of profitability - performance, which covers operating expenses while the rest is profit. 


\begin{tabular}{|c|c|c|}
\hline \multicolumn{3}{|c|}{ Year Till Date Sep 2011} \\
\hline Merchandise & AED Millions & Chare \\
\hline Perfumes & 548 & $14.5 \%$ \\
\hline Gold & 432 & $11.4 \%$ \\
\hline Electronics & 296 & $7.8 \%$ \\
\hline Cosmetics & 229 & $6.1 \%$ \\
\hline Confectionery & 284 & $7.5 \%$ \\
\hline Others & 1,991 & 52.7 \\
\hline Total & 3,780 & $100.0 \%$ \\
\hline
\end{tabular}

Table 3 - Dubai Duty Free - Sales by Merchandise Category

Source: Peter and Anandkumar (2011)

Table 4 illustrates the rate of gross margin (gross profit) and net margin (net profit) for the leading retailer that renders a service to tourists - Dufry's HY.

\begin{tabular}{ccc}
\hline & 2011 & 2010 \\
\hline Gross profit & $58.0 \%$ & $57.0 \%$ \\
\hline Net Earnings & $4.8 \%$ & $4.8 \%$ \\
\hline
\end{tabular}

Table 4 - Dufry Group HY-Gross Profit and Net Earnings Source: Peter and Anandkumar (2011).

According to the market and financial characteristics, duty free shops are highly profitable. The data presented speak in favor of this: in the coming years, the estimated rate of net margin of the duty free business in Turkey of Net Holding company will be high: 2010 - 14.0\% 2011 -14.0\%, 2012 - 14.0\%, 2013 - 13.0\%, 2014 - 13.0 \%, 2015 - 13.0\%, 2020 - 13.0\%, $2021-13.0 \%$ and $2024-13.0 \%$ (Net Holding, Oyak Securitiea Estimates).

In principle, on the basis of all the characteristics, it can be concluded that the cross-border shopping is highly profitable, which is quite understandable when one takes into account the fact that foreign buyers - mostly tourists, purchase goods with high gross margin characteristics.

\section{CONCLUSION}

The dynamics of cross-border purchases is being more and more pronounced. It is increasingly treated as a separate target segment of the retail market. Determinants of cross-border purchases are various. In addition to price differentiation, the role of the brand is also becoming more significant. These are the prerequisites for more efficient management of cross-border shopping as a determinant of the overall performance of global retailers.

Concerning the types of channels of cross-border shopping, it is the online channel that is becoming more and more important. This is quite understandable if we take into consideration a number of advantages it provides compared to other marketing channels of cross-border shopping (price transparency, shopping in any currency during the day and from anywhere, etc.). By keeping the potential customers fully informed, barriers to online cross-border shopping have been reduced to a great extent.Cross-border shopping is one of the multiple influential factors. It affects the development of retail formats structure, tourism, tax revenue, the living standards of cross-border customers and the performance of retail companies. Through effective management of cross-border shopping via the strong control of influential factors, the overall performance of retail companies that render a service to cross-border shoppers can be improved significantly.

\section{REFERENCES}

Chandra, A., Head, K., Tappata, M. (2011) Consumer Arbitrage a Porous Border. London : Centre for Economic Policy Research.

Friedrich, W., Sattler, K. (2005) Shopping Tourism in Germany: Impulses in the development of tourism and retail commerce in Germany. Köln: Institut für Sozialforschung. Available from: http://www.isg-institut.de/download/Shoppingtourismus_short_engl. pdf[accessed 17 March 2012 ]. 
Gopinath, G., et al. (2011) International Prices, Costs, and Markup Differences. American Economic Review. 101 (6), 2450-2486.

Hsu, C.H., Chen, C.H. (2011) Analyzing the purchase motivation of online shopping for health food. African Journal of Business Management. 5 (12), 4699-4703.

Lau, H.f., Sin, L.Y. m., Chan, K.K.C. (2005) Chinese CrossBorder Shopping: An Empirical Study. Journal of Hospitality \& Tourism Research. 29 (1), 110-133.

Leal, A., López-Laborda, J., Rodrigo, F. (2010) Cross-Border Shopping: A Survey. International Advances in Economic research. 16 (2), 135-148.

Leal, A., López-Laborda, J., Rodrigo, F. (2009) Prices, taxes and automotive fuel cross-border shopping. Energy Economics. 31 (2), 225-234.

LIoyd, A.E., Yip, L.S.C., Luk, S.T.K. (2011) An examination of the differences in retail service evaluation between domestic and tourist shoppers in Hong Kong. Tourism Management. 32 (3), 520-533.

Lukić, R. (2011) Evaluacija poslovnih performansi u maloprodaji. Belgrade: Faculty of Economics, University of Belgrade. (in Serbian)

Patrick, P., Florian, S. (2011) Determinants of cross border shopping in the border region of the Netherlands, Belgium and Germany: theory and empirical results. European Journal of Management. 11 (4), 12-22.
Peter, S., Anandkumar, V. (2011) A study on the sources of competitive advantage of Dubai as a Shopping Tourism Destination. International Business Research Conference [online]. Available from: http: // wbiconpro. com/510-Sangeeto.pdf [accessed 17 May 2012].

Singh, K. (2011) Cross-Border Shopping: Implications for State Fiscal Competition in Multiple Tax Instruments. Thesis, (PhD). University of Kentucky.

Suchánek, P. (2010) Business intelligence as a support of ecommerce systems in connection with decision making and cross-border online shopping. Journal of Applied Economic Sciences. 5 (1), 94-102.

The European Consumer Centres' Network (2011) Online cross-border mystery shopping - state of the e-union [online]. Available from: http://ec.europa. eu/consumers/ecc/docs/mystery_shopping_report_ en.pdf [accessed 25 May 2012].

Timothy, D.J., Butler, R.W. (1995) Cross-Border Shopping A North American Perspective. Annals of Tourism Research. 22 (1), 16-34.

Tömöri, M. (2010) Investigating Shopping Tourism Along the Borders of Hungary: A Theoretical Perspective. GeoJournal of Tourism and Geosites. 6 (2), 202-210.

$\mathrm{Xu}$, Y., McGehee, N.G. (2012) Shopping behavior of Chinese tourists visiting the United States: Letting the shoppers do the talking. Tourism Management. 33 (2), 427-430.

\section{EFEKTI PREKOGRANIČNIH KUPOVINA TURISTA NA PERFORMANSE U MALOPRODAJI}

\section{Rezime:}

Jedna od glavnih tvorevina u savremenoj maloprodaji koja postaje sve zastupljenija jeste koncept prekogranične kupovine. Faktori koji doprinose sve bržem razvoju prekogranične kupovine su brojni, poput diferenciranja cena, kvaliteta, pogodnosti, demografskih i socijalnih karakteristika, dobre organizacione structure u modernoj maloprodaji kao i mnogih drugih. Među faktorima koji imaju uticaj, uloga diferenciranja cene robe i usluga je veoma bitna i na nju takođe utiču brojni faktori, poput poreza na dodatu vrednost, marže profita, operativnih troškova, inflacije, diferenciranja organizacione strukture u maloprodaji, primene naprednih informacionih i komunikacijskih tehnologija kao i mnogih drugih. Prekogranične kupovine same po sebi predstavljaju bitan faktor koji utiče na razvoj turizma, ciljano maloprodajno tržište, performanse maloprodajnih kompanija, i životni standard. Sve zajedno, to ima pozitivan uticaj na ukupne performanse nacionalne ekonomije.

\section{Ključne reči:}

diferenciranje cena, faktori, kupci-turisti, performance. 